\title{
A METHODOLOGICAL APPROACH TO THE STRATEGIC ANALYSIS OF FOOD SECURITY
}

\author{
Anastasiia Mostova' \\ Alfred Nobel University, Ukraine
}

\begin{abstract}
The objective of present work is to substantiate the use of tools for strategic analysis in order to develop a strategy for the country's food security under current conditions and to devise the author's original technique to perform strategic analysis of food security using a SWOT-analysis. The methodology of the study. The article substantiates the need for strategic planning of food security. The author considers stages in strategic planning and explains the importance of the stage of strategic analysis of the country's food security. It is proposed to apply a SWOT-analysis when running a strategic analysis of food security. The study is based on the system of indicators and characteristics of the country's economy, agricultural sector, market trends, material-technical, financial, human resources, which are essential to obtain an objective assessment of the impact of trends and factors on food security, and in order to further develop the procedure for conducting a strategic analysis of the country's food security. Results of the study. The procedure for strategic analysis of food security is developed based on the tool of a SWOT-analysis, which implies three stages: a strategic analysis of weaknesses and strengths, opportunities and threats; construction of the matrix of weaknesses and strengths, opportunities, and threats (SWOT-analysis matrix); formation of the food security strategy based on the SWOT-analysis matrix. A list of characteristics was compiled in order to conduct a strategic analysis of food security and to categorize them as strengths or weaknesses, threats, and opportunities. The characteristics are systemized into strategic groups: production, market; resources; consumption: this is necessary for the objective establishing of strategic directions, responsible performers, allocation of resources, and effective control, for the purpose of further development and implementation of the strategy. A strategic analysis of food security consists of two blocks: the analyses of the external and internal environment. It is proposed, in order to improve the validity of the strategic analysis, to evaluate strengths and weaknesses, threats, and opportunities at the time of analysis, as well as to explore the trends of their change in dynamics. For this purpose, the author proposed establishing the persistence of the identified strengths, weaknesses, threats, and opportunities. To accomplish it, the persistent strengths of possibilities include, in the author's opinion, characteristics with a positive dynamic over the examined period while the persistent weaknesses and threats include, accordingly, those with a negative dynamic. Practical implications. Result of the present research is the advanced matrix of a SWOT-analysis of food security, which complements traditional method with the grouping according to the basic strategic groups of food security (production, market, resources, consumption), as well as the level of persistence of strengths and weaknesses, threats and opportunities, depending on the dynamics of the proposed characteristics. The main practical outcome of the developed procedure is the list of strategic recommendations based on the identified strengths and weaknesses, threats and opportunities of food security, depending on the level of their persistence. The value and originality of the scientific results are in that as a result of the proposed procedure, there will be built an effective instrument for carrying out a strategic analysis of the country's food security. Based on the strategic analysis of the persistent strengths, the author identified the main com-petitive advantages of the country's food security, which are to be strengthened, while implementing supporting strategic measures and control. It is established that the non-persistent strengths of food security of Ukraine would require a more effective management in comparison with those persistent, as well as development of an efficient mechanism of government support and regulation. Minimization of the impact of persistent weaknesses on the level of food security and their transformation into strengths should be carried out under the condition of reforming the social policy of the state and creating a system of the state support for the agricultural sector. The task on resolving the problems associated with the impact of threats in accordance with the level of their persistence has to be dealt with gradually, with the further development of strategic measures to neutralize and protect food security and the factors that affect it, in particular, to utilize the potential of external opportunities.
\end{abstract}

Key words: strategic planning, strategic analysis, food security, SWOT-analysis.

JEL Classification: Q10, Q18, O13, O21

Corresponding author:

${ }^{1}$ Department of International Marketing, Alfred Nobel University.

E-mail: nastya25061987@gmail.com 


\section{Introduction}

The period of transition to market relations calls for the ever-growing realization of the importance of strategic planning with a search for applying its methods at the national level. Widespread use of strategic planning, employed nationally when devising strategies for the development of state economic management, is hindered by the inadequate level of knowledge about the methods and tools for the development of strategic plans, as well as their limited adaptability to the conditions of the national market. A given problem also applies to the country's food security.

Theoretical and methodological aspects of strategic planning were addressed in numerous scientific studies. The works by Ukrainian and foreign authors in the field of strategic planning and strategic management, which in detail highlight regularities of formation, the features of methodology, and the logic of evolution of strategic planning and management, include studies by R. L. Ackoff, H. Mintzberg, P. Doyle, A. Thompson, A. J. Strickland, and others. However, methodological approaches and the implementation of the strategy of the country's food security require further research and improvement.

\section{The tool of SWOT-analysis in the scientific literature}

Investigation of possibilities of applying a SWOTanalysis as a strategic management tool at the general economic level, at the level of the agricultural sector of the economy, including an analysis of the state of food security, was addressed in the scientific work of national experts.

In particular, the study by S.M. Khalatur reveals the state of the agro-industrial complex of Ukraine under conditions of a global food problem and reports the SWOT-analysis conducted in order to specify potential internal advantages, internal shortcomings, potential external opportunities, and potential external threats (Halatur, 2015). The author provided general recommendations on further development of the agri-food industry sector in Ukraine. However, methodological and analytical capabilities of the tool of a SWOT-analysis for the evaluation of country's food security and for the development of strategic directions regarding its implementation require deeper research.

In the paper, the SWOT-analysis of the food security in Ukraine was conducted using a classic algorithm of a given technique (Varaskina, 2016). The author identified the strengths and weaknesses, threats and opportunities of food security; however, given the results of the analysis, he failed to construct the matrix of strategies and appropriate strategic directions for strengthening food security through the substantiation of strategic planning.

O.V. Skidan, in a study on the creation of a regional agricultural policy of food security, performed a SWOT- analysis of the current state of food security in the region (Skidan, 2004). The scientist, however, while substantiating the practical aspects of running a SWOTanalysis of food security, did not take into consideration strategic directions for ensuring a high level of food security at the national level based on the results of the strategic analysis.

Thus, it should be noted that SWOT analysis as a tool of strategic analysis and planning of food security is of interest to scientists who study a given problem. There are no, however, at present any substantiated scientific approaches to the strategic analysis of food security using a SWOT-analysis, which would be based on the quantitative evaluation of strengths and weaknesses, threats and opportunities by employing a system of characteristics and indicators and would account for their changes in dynamic, and which would make it possible to form appropriate strategies taking into consideration the results of the conducted analysis in order to establish optimal strategic priorities and further effective allocation of resources when creating and implementing the strategies of food security.

\section{Procedure for performing a SWOT-analysis}

At present, there are a large number of scientific approaches to defining a methodology for strategic planning, and this very term refers to a set of specialized methods, principles, and rules for making management decisions aimed at achieving long-term goals of the examined object, improving its competitiveness, creating the base for successful and persistent development (Lebedev, 2008).

The methods and tools for strategic planning of food security are advisable to group according to such stages as the analysis of environment, definition of the mission and goals, the choice of strategy and basic scenarios, development of strategy, implementation of the strategy, evaluation and control over the implementation of the strategy (Aaker, 2002). When substantiating the application of a method or a tool, one should take into consideration the specificity of food security, which is characterized by the dependence on a number of factors.

One of the most important stages in the formation of a food security strategy is considered to be a strategic analysis of the external and internal environment since its methodical substantiation affects the efficiency of further strategic, tactical, and operational measures and managerial activities.

At the stage of strategic analysis of the environment, the most common method is the SWOT-analysis, which is a classic tool for strategic planning of development of enterprises and makes it possible to determine the cause of efficient or inefficient activity of the examined object and establish appropriate directions in strategy depending on the results of the analysis. 
SWOT-analysis has been recently successfully applied at the national level. It is a brief analysis of external information, based on which a conclusion is drawn about the direction, in which the examined object must evolve, and resources are allocated for the areas of activity. The result of the analysis is the development of a strategy or a hypothesis for further verification. The classic SWOT-analysis implies determining the strengths and weaknesses of the object's activity, potential external threats, and favourable opportunities, as well as their evaluation relative to strategically important goals and objectives (Thompson, Strickland, 1998). The result of planning is a SWOT-matrix, the matrix of opportunities and the matrix of threats.

\section{Results of the development of a procedure for conducting a SWOT analysis of the country's food security}

We shall proceed to the consideration of the developed procedure of SWOT-analysis of the country's food security.

Figure 1 shows implementation algorithm of the proposed technique.

Thus, the first stage of the algorithm implies conducting a strategic analysis.

We shall start by making up a list of characteristics for the strategic analysis of food security in order to subsequently relate the specified characteristics to strengths or weaknesses, threats and opportunities. The characteristics will be matched with specific indicators whose estimation will be based on the open analytical information (State Statistics Service of Ukraine, 2018).
Characteristics with the indicators are advisable to categorize in groups (Mostova, Vinichenko, 2016):

1. Production. This group will include those characteristics that are associated with the analysis of trends in production, the production capacity of the sector, and its prospects for investment, for example:

- Sufficient production of food products (production sufficiency index);

- Profitability of agriculture (profitability level optimality index);

- Productivity at agricultural enterprises (rate of growth in labour productivity in agriculture).

2. Market. This group reflects conditions, under which food products are supplied to the country, as well as trends in foreign trade of foodstuffs and their impact on the state of the agricultural sector, which is to be evaluated by the following characteristics:

- Food independence (food independence optimality index);

- Rise in prices for agricultural products (price rise optimality index);

- Balance of foreign trade in food commodities (trade balance optimality index).

3. Resources. This group is to include those characteristics that make it possible to estimate food supplies, and to provide the agricultural sector with means of production, labour, and other resources, such as

- Sufficient grain reserve in the state resources (index of stock sufficiency);

- Self-sufficiency of food products (food selfreliance index);

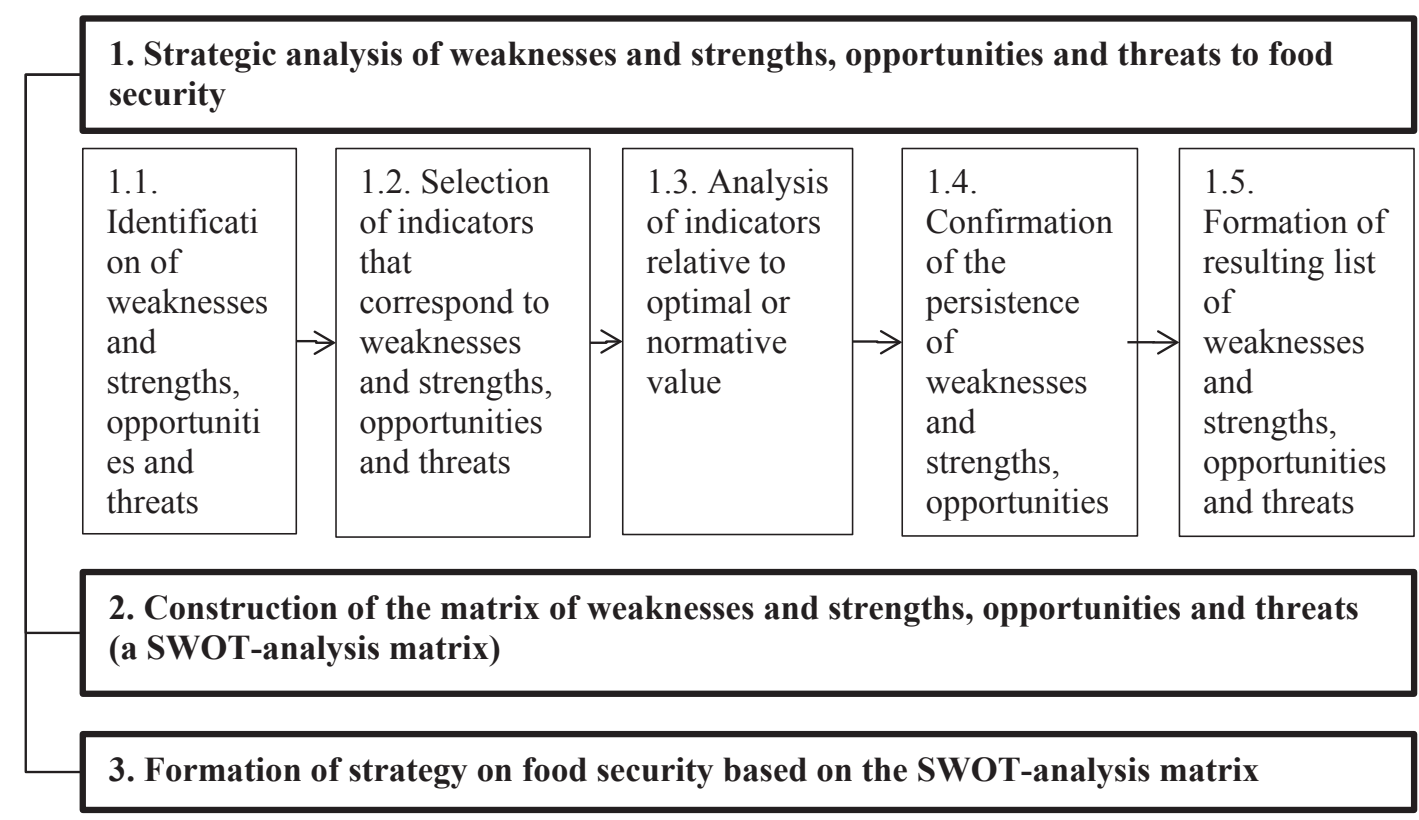

Fig. 1. Algorithm for performing a SWOT-analysis on food security

Source: developed by the author 
- Sufficiency of food product consumption (consumption sufficiency index).

4. Consumption. In the author's opinion, this group might include those characteristics that indicate the availability of food and its quality, balanced nutrition, labour wages in the country, the state of land use, in particular:

- Economic affordability of food products (index of economic affordability of food products)

- Balanced food consumption (consumption balance index);

- Daily nutritional energy value (daily nutritional energy value optimality index).

Those strategic groups of indicators that can be attributed to external opportunities or threats are advisable to categorize as follows.

1. Production:

- Investment attractiveness of the agrarian sector of economy (the level of profitability of investments into agricultural production, the growth rate of capital investment, the growth rate of foreign direct investment, etc.);

- Attractiveness of the agricultural sector for employees (the ratio of wage in agriculture to the total average monthly salary in the country);

- Production of staple food products (the mean arithmetic growth rate of the volume of food production);

- The volume of production in agriculture (growth rate of production output);

- Production potential of the agricultural industry (the mean arithmetic growth rate of yield, livestock productivity, etc.).

2. Market:

- Foreign trade in food products (the mean arithmetic growth rate of import and export of products).

3. Resources:

- Availability of basic means of agricultural production (the mean arithmetic growth of availability of agricultural machines per 10 thousand hectares, new capacities, quantity of livestock, sown areas);

- Production costs of agricultural products (optimality index of production costs of agricultural products);

- Availability of employees in agriculture (the growth rate of the number of employees in agriculture).

4. Consumption:

- Environmental consequences of land use (the mean arithmetic growth rate of fertilization, re-cultivated soil);

- The structure of land use (land use balance index);

- The unemployment rate in the country (optimality index of the rate of unemployment growth)

- The level of labour remuneration (index of real wages in the country, the ratio of wages in agriculture to the total average monthly salary in the country, and other).

There will be conducted a comparative analysis for each indicator against the optimal or normative value. As a result, indicators will be presented in the form of a system of relative magnitudes in order to obtain an objective assessment of trends in food security in comparison with the regulatory values or those favourable by certain criteria. All indicators will be of the same dimensionality to ensure that they can be compared not only with the optimal or normative values, but also against each other.

Thus, the value of the indicator for the last year of the examined period that is equal to or greater than 1 , reflects the positive trend and will be attributed to strengths and that one less than 1, accordingly, negative, and thereby will be attributed to weaknesses. As a result, based on the obtained information, we shall construct a matrix of strengths and weaknesses, threats and opportunities.

To increase the effectiveness of strategic analysis, it is necessary not only to establish strengths and weaknesses at the time of conducting the analysis but also to examine trends of the mentioned aspects in dynamics. For this purpose, it is proposed to verify the persistence of the identified strengths and weaknesses, based on which, the persistent strengths and weaknesses will include only those that will be characterized, accordingly, by retaining a positive and a negative trend in a change in the indicator over the examined period. Similarly confirmed is the persistence of the specified threats and opportunities.

Figure 2 shows a structure of the improved matrix of SWOT-analysis on food security.

Distinguishing between persistent and non-persistent strengths and weaknesses is required in order to set strategic priorities and further effective resource allocation when developing a strategy. Persistent strengths will form the main strategic advantages that will support weaknesses and eliminate threats.

Persistent weaknesses require priority strategic measures aimed at their eradication, that is, to start with converting them into the non-persistent weaknesses, and subsequently - into the non-persistent strengths.

Non-persistent strengths must be the focus of attention as supporting strategic advantages, which are subsequently necessary to stabilize and maintain at the persistent level.

Non-persistent weaknesses have to be transformed into non-persistent strengths provided the effective strategic measures are put in place.

Thus, the block of strategic analysis of the internal environment of food security implies identifying the strengths and weaknesses and establishing their persistence. Maximum attention must be paid to persistent weaknesses; increased attention is to be paid to the non-persistent weaknesses, while nonpersistent strengths will require supporting measures 


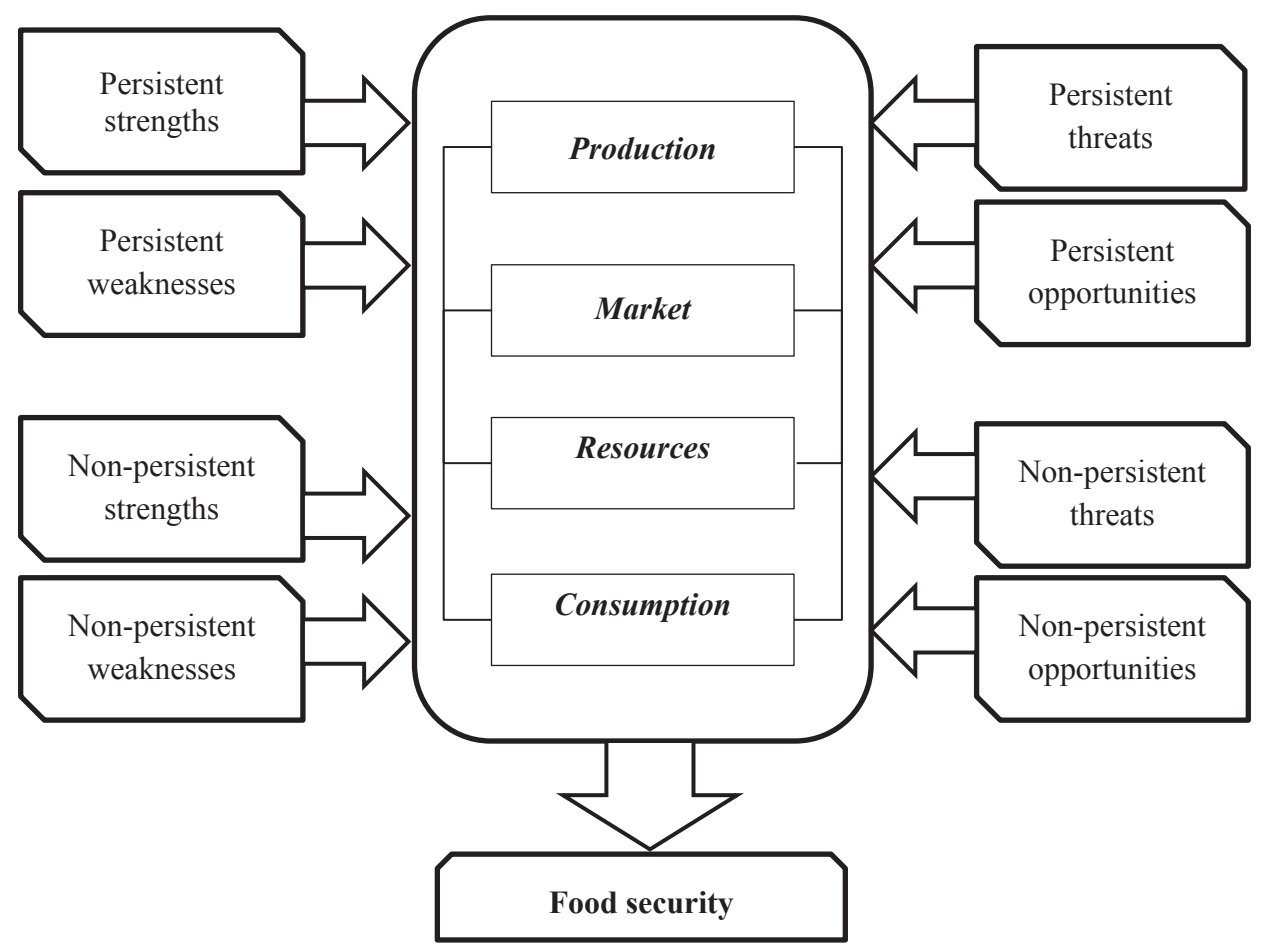

Fig. 2. The logical structure of the improved matrix of SWOT-analysis of food security

Source: developed by the author

whose intensity will depend on specific strategic priorities of the state policy in the agrarian, trade, and social fields. Persistent strengths should be used for the implementation of other measures in the strategy of food security.

Strategic analysis of the external environment of food security implies an assessment of the threats and opportunities in order to establish their persistence. The specified components are external relative to food security, but at the level of the state, they are to be managed. Persistent opportunities should be considered as the main factor that in the strategic perspective will exert a positive impact on supporting the level of food security at the appropriate level and will help prevent the threats. When developing a strategy, and in the course of strategic planning of food security, it is appropriate, in order to enhance its level, to utilize both persistent opportunities and persistent strengths.

Persistent threats require increased attention and maximum concentration of state resources to minimize their negative impact on the level of food security.

Non-persistent opportunities should be taken into consideration in the course of strategic planning with respect to the uncertainty of the external environment, by introducing to the strategy for food security separate measures that would strengthen the non-persistent opportunities.

Non-persistent threats under conditions of effective management have to be converted into non-persistent opportunities or form the basis for the development of a block of strategic measures in order to neutralize and protect food security and factors, on which it directly depends.

It is possible to conclude that the block of strategic analysis of external environment of food security includes the assessment of threats and opportunities and establishes their persistence. Maximum attention should be paid to persistent threats and to developing measures to neutralize their impact, increased attention is to be paid to the non-persistent threats. Persistent and non-persistent threats must be converted into opportunities for food security and become the source of its further strengthening. Non-persistent opportunities should be backed up by appropriate supporting strategic measures related to the state regulation of agricultural, foreign trade, social policy. Persistent opportunities require strategic measures aimed at their maximum implementation in the long term.

Next, it is necessary to construct an expanded matrix of weaknesses and strengths, opportunities and threats (matrix of SWOT-analysis of food security). A traditional matrix includes a resulting list of the strengths, weaknesses, opportunities and threats, which will additionally specify the indicated persistent strengths and weaknesses, as well as the opportunities and threats. In addition to the existing approach, the improved matrix of SWOT-analysis on food security implies the construction of the indicated main elements relative to 
the specified basic strategic groups: production, market, resources consumption.

\section{Practical implementation of the procedure for conducting a SWOT-analysis of the country's food security}

We shall proceed to the consideration of practical aspects of the examined development. First, we shall demonstrate the implementation of the proposed procedure of strategic analysis of food security using the strengths and weaknesses as an example. Results of calculations are given in Table 1. Strategic analysis of the opportunities and threats to food security will be performed in a similar fashion (Table 2).

The next stage of strategic analysis is the assessment of dynamics of strengths, weaknesses, threats, and opportunities of food security for the further confirmation of their persistence. For this purpose, based on the performed analysis (Table 1 and Table 2),

Table 1

Indicators for the strategic analysis of food security and their further categorization into strengths or weaknesses

\begin{tabular}{|c|l|c|c|c|c|c|}
\hline Strategic groups & \multicolumn{1}{|c|}{ Indicators } & 2011 & 2012 & 2013 & 2014 & 2015 \\
\hline \multirow{4}{*}{ Production } & Production sufficiency index & 1.806 & 1.936 & 1.820 & 2.081 & 2.128 \\
\cline { 2 - 7 } & Profitability level optimality index & 0.643 & 0.543 & 0.277 & 0.310 & 1.017 \\
\cline { 2 - 7 } & Rate of growth in labour productivity in agriculture & 1.245 & 0.966 & 1.260 & 1.132 & 0.980 \\
\hline \multirow{4}{*}{ Market } & Food independence optimality index & 18.619 & 24.680 & 22.128 & 20.239 & 34.059 \\
\cline { 2 - 7 } & Price rise optimality index & 1.018 & 1.282 & 1.087 & 0.910 & 0.797 \\
\cline { 2 - 7 } & Trade balance optimality index & 11.111 & 20.060 & 18.528 & 19.892 & 32.137 \\
\hline \multirow{3}{*}{ Resources } & Index of stock sufficiency & 1.150 & 1.263 & 1.140 & 1.205 & 1.272 \\
\cline { 2 - 7 } & Food self-sufficiency index & 1.128 & 1.055 & 1.150 & 1.204 & 1.218 \\
\cline { 2 - 7 } & Food self-reliance index & 0.880 & 0.879 & 0.888 & 0.866 & 0.816 \\
\hline \multirow{3}{*}{ Consumption } & Index of economic affordability of food products & 1.170 & 1.198 & 1.198 & 1.156 & 1.130 \\
\cline { 2 - 7 } & Consumption balance index & 0.497 & 0.519 & 0.532 & 0.525 & 0.514 \\
\cline { 2 - 7 } & Daily nutritional energy value optimality index & 1.180 & 1.182 & 1.188 & 1.176 & 1.120 \\
\hline
\end{tabular}

Source: developed by the author

Table 2

Indicators for the strategic analysis of food security and their further categorization into opportunities and threats

\begin{tabular}{|c|c|c|c|c|c|c|}
\hline Strategic groups & Indicators & 2011 & 2012 & 2013 & 2014 & 2015 \\
\hline \multirow{8}{*}{ Production } & Level of profitability of investments into agricultural production & 1.513 & 1.400 & 0.801 & 1.165 & 3.490 \\
\hline & Growth rate of capital investments & 1.477 & 1.143 & 0.977 & 0.986 & 1.594 \\
\hline & Growth rate of direct foreign investments & 1.074 & 1.008 & 0.990 & 1.066 & 0.794 \\
\hline & $\begin{array}{l}\text { Ratio of wage in agriculture to the total average monthly salary in the } \\
\text { country }\end{array}$ & 0.680 & 0.670 & 0.695 & 0.711 & 0.749 \\
\hline & Mean arithmetic growth rate of the volume of production of foodstuffs & 1.134 & 1.016 & 0.968 & 1.082 & 0.917 \\
\hline & Mean arithmetic growth rate of the volume of food production & 1.339 & 1.033 & 1.173 & 1.209 & 1.466 \\
\hline & Mean arithmetic growth rate of crop yield & 1.230 & 0.985 & 1.119 & 1.041 & 0.995 \\
\hline & Mean arithmetic growth rate of productivity & 1.038 & 1.034 & 1.008 & 0.991 & 0.987 \\
\hline \multirow{2}{*}{ Market } & Mean arithmetic growth rate of food products import & 0.911 & 0.994 & 1.103 & 0.950 & 0.680 \\
\hline & Mean arithmetic growth rate of food products export & 1.087 & 1.465 & 1.223 & 0.981 & 1.255 \\
\hline \multirow{6}{*}{ Resources } & $\begin{array}{l}\text { Mean arithmetic growth rate of availability of agricultural machines } \\
\text { per } 10 \text { thousand hectares of soil }\end{array}$ & 0.870 & 0.957 & 1.057 & 0.935 & 0.974 \\
\hline & Mean arithmetic growth rate of new capacities & & 19.861 & 1.331 & 1.770 & 0.396 \\
\hline & Mean arithmetic growth rate of livestock population & 0.991 & 1.029 & 1.022 & 0.879 & 0.966 \\
\hline & Growth rate of sown areas & 1.027 & 1.005 & 1.019 & 0.962 & 0.988 \\
\hline & Optimality index of production costs of agricultural products & 0.887 & 0.950 & 1.044 & 0.706 & 0.719 \\
\hline & Growth rate of the number of employees in agriculture & 1.151 & 1.056 & 1.094 & 0.986 & 0.971 \\
\hline \multirow{6}{*}{ Consumption } & Mean arithmetic growth rate of fertilization & & 1.053 & 1.027 & 0.785 & 1.022 \\
\hline & Optimality index of the growth rate of unemployment & 1.087 & 1.144 & 1.082 & 0.935 & 0.798 \\
\hline & Index of real wages in the country & 0.680 & 0.670 & 0.695 & 0.711 & 0.749 \\
\hline & $\begin{array}{l}\text { Ratio of wage in agriculture to the total average monthly salary in the } \\
\text { country }\end{array}$ & & 1.475 & 1.173 & 0.492 & 0.833 \\
\hline & Mean arithmetic growth rate of the area of re-cultivated soil & 0.615 & 0.614 & 0.613 & 0.613 & 0.612 \\
\hline & Land use balance index & 1.151 & 1.056 & 1.094 & 0.986 & 0.971 \\
\hline
\end{tabular}

Source: developed by the author 
we shall group separately the strengths and weaknesses with a positive and a negative dynamic over the examined period. Similarly analysed are the detected threats and opportunities. Results of systematization are given in Table 3.

Next, we shall construct the improved matrix of SWOT-analysis of food security, which will include the resulting list of strengths, weaknesses, opportunities and threats in the context of basic strategic groups (production, market, resources, consumption) (Table 4, Table 5).

Strategic directions for improving the level of food security in accordance with the results of the analysis are advisable to develop in terms of strategic groups depending on the persistence of the identified strengths, weaknesses, opportunities, and threats.

Thus, based on the strategic analysis of the persistent strengths, we identified the main competitive advantages that the country's food security has, and which should be strengthened at the national level. These include the sufficiency of food production, food independence, the balance of foreign trade in foodstuffs, self-sufficiency with food products, the sufficiency of grain reserves in the state resources. Thus, the main strategic directions that must become the foundation of the sustainable level of food security are the following: increasing the volume of production, maintaining constant volumes of imported foodstuffs, control over foreign trade policy in order to keep the optimum ratio of export and import, improvement of market infrastructure, implementation of the effective policy for managing state reserves. It should be noted that, based on the data of analysis, the indicated characteristics require only supportive strategic measures and control, rather than fundamental changes.

The non-persistent strengths of food security of Ukraine require more effective management in comparison with those persistent. An increase in the proportion

Table 3

List of strengths and weaknesses, threats and opportunities of food security and the confirmation of their persistence

\begin{tabular}{|c|c|}
\hline Strengths & Strengths with a positive dynamic \\
\hline $\begin{array}{l}\text { 1. Sufficient production of food products } \\
\text { 2. Profitability of agriculture } \\
\text { 3. Food independence } \\
\text { 4. Self-sufficiency of food products } \\
\text { 5. Balance of foreign trade in food commodities } \\
\text { 6. Economic affordability of food products } \\
\text { 7. Daily nutritional energy value } \\
\text { 8. Sufficient grain reserves in the state resources }\end{array}$ & $\begin{array}{l}\text { 1. Sufficient production of food products } \\
\text { 2. Food independence } \\
\text { 3. Self-sufficiency of food products } \\
\text { 4. Balance of foreign trade in food commodities } \\
\text { 5. Sufficient grain reserves in the state resources }\end{array}$ \\
\hline Weaknesses & Weaknesses with a negative dynamic \\
\hline $\begin{array}{l}\text { 1. Balanced food consumption } \\
\text { 2. Price indices for agricultural products } \\
\text { 3. Sufficiency of food products consumption } \\
\text { 4. Labour productivity at agricultural enterprises }\end{array}$ & $\begin{array}{l}\text { 1. Balanced food consumption } \\
\text { 2. Sufficiency of food products consumption }\end{array}$ \\
\hline Opportunities & Opportunities with a positive dynamic \\
\hline $\begin{array}{l}\text { 1. Investment attractiveness of the agrarian sector of economy } \\
\text { 2. Volume of production in agriculture } \\
\text { 3. Unemployment rate in the country } \\
\text { 4. Foreign trade in food products }\end{array}$ & 1. Volume of production in agriculture \\
\hline Threats & Threats with a negative dynamic \\
\hline $\begin{array}{l}\text { 1. Investment attractiveness of the agrarian sector of economy } \\
\text { 2. Attractiveness of the agricultural sector for workers } \\
\text { 3. Availability of employees in agriculture } \\
\text { 4. Production potential of the agricultural industry } \\
\text { 5. Availability of basic means of agricultural production } \\
\text { 6. Availability of livestock at agricultural production } \\
\text { 7. Sown areas of agricultural crops } \\
\text { 8. Production costs of agricultural products } \\
\text { 9. Production of staple food products } \\
\text { 10. Influence of fertilization on the condition of soil and product quality } \\
\text { 11. Level of labour remuneration in the country } \\
\text { 12. Level of labour remuneration in agriculture } \\
\text { 13. Environmental consequences of land use } \\
\text { 14. Structure of land use } \\
\text { 15. Foreign trade in food products }\end{array}$ & $\begin{array}{l}\text { 1. Attractiveness of the agricultural sector for workers } \\
\text { 2. Availability of employees in agriculture } \\
\text { 3. Level of labour remuneration in agriculture }\end{array}$ \\
\hline
\end{tabular}

Source: developed by the author 
Table 4

The improved matrix of SWOT-analysis of the country's food security (strategic analysis of strengths and weaknesses)

\begin{tabular}{|l|l|l|l|l|}
\hline Groups of indicators & \multicolumn{1}{|c|}{ Production } & \multicolumn{1}{c|}{ Market } & \multicolumn{1}{c|}{ Resources } & \multicolumn{1}{c|}{ Consumption } \\
\hline Persistent strengths & $\begin{array}{l}\text { Sufficient } \\
\text { production of food } \\
\text { products }\end{array}$ & $\begin{array}{l}\text { Food independence. } \\
\text { Balance of foreign trade in } \\
\text { food commodities. }\end{array}$ & $\begin{array}{l}\text { Self-sufficiency of food } \\
\text { products. } \\
\text { Sufficient grain reserves in } \\
\text { the state resources. }\end{array}$ & \\
\hline $\begin{array}{l}\text { Persistent } \\
\text { weaknesses }\end{array}$ & & $\begin{array}{l}\text { Balanced food consumption. } \\
\text { Sufficiency of food products } \\
\text { consumption. }\end{array}$ \\
\hline $\begin{array}{l}\text { Non-persistent } \\
\text { strengths }\end{array}$ & $\begin{array}{l}\text { Profitability of } \\
\text { agriculture }\end{array}$ & $\begin{array}{l}\text { Economic affordability of food } \\
\text { products. } \\
\text { Daily nutritional energy value. }\end{array}$ \\
\hline $\begin{array}{l}\text { Non-persistent } \\
\text { weaknesses }\end{array}$ & $\begin{array}{l}\text { Productivity } \\
\text { at agricultural } \\
\text { enterprises }\end{array}$ & $\begin{array}{l}\text { Rise in prices for } \\
\text { agricultural products }\end{array}$ & & \\
\hline
\end{tabular}

Source: developed by the author

of food expenses in the budget of households leads to the lower economic affordability of consumption. Enhancing the economic affordability of food products, as well as the daily nutritional energy value, should become strategic directions of the agricultural policy and reforms in the state's social policy. It is also advisable to develop an effective mechanism of state support for agricultural enterprises in order to increase the profitability of agriculture through the optimization of costs, which in turn will make it possible to keep food prices unchanged.

The top priority task at the strategic level must be the minimization of the influence of persistent weaknesses on the level of food security, as well as the development of a plan of action for the elimination of weaknesses or converting weaknesses into strengths. As the performed analysis revealed, a weak link in food security is the balance and sufficiency of food products consumption. Therefore, it is necessary to plan strategic measures to reform social policy of the state and to create a system of state support of agricultural producers in cattle breeding.

The non-persistent weaknesses, which in terms of food security include labour productivity at agricultural enterprises and rise in prices for agricultural products, require improving the state regulation of food market and the development of measures to attract workers in the agricultural sector and to motivate people to work at agricultural enterprises in the long term. The problem of mismatch between the rate of rising of food prices and wages of the population requires a comprehensive socioeconomic policy aimed at improving the standards of life quality of people and their social protection.

The persistent opportunities in the food security of Ukraine include the stable growth of the volume of production in agriculture. The agricultural sector of the national economy is capable of providing the required volume of food production in the country. In terms of strategic perspective, this factor must be focused on

Table 5

The advanced matrix of SWOT-analysis of the country's food security (strategic analysis of opportunities and threats)

\begin{tabular}{|l|l|l|l|l|}
\hline Groups of indicators & \multicolumn{1}{|c|}{ Production } & \multicolumn{1}{c|}{ Market } & \multicolumn{1}{c|}{ Resources } & \multicolumn{1}{c|}{ Consumption } \\
\hline $\begin{array}{l}\text { Persistent } \\
\text { opportunities }\end{array}$ & $\begin{array}{l}\text { Volume of production in } \\
\text { agriculture }\end{array}$ & $\begin{array}{l}\text { Attractiveness of the } \\
\text { agricultural sector for workers }\end{array}$ & $\begin{array}{l}\text { Availability of workers in } \\
\text { agriculture }\end{array}$ & $\begin{array}{l}\text { Level of labour remuneration } \\
\text { in agriculture }\end{array}$ \\
\hline $\begin{array}{l}\text { Nersistent threats } \\
\text { opportunities }\end{array}$ & $\begin{array}{l}\text { Investment attractiveness of the } \\
\text { agrarian sector of the economy. }\end{array}$ & $\begin{array}{l}\text { Foreign trade in } \\
\text { food products }\end{array}$ & $\begin{array}{l}\text { The unemployment rate in the } \\
\text { country }\end{array}$ \\
\hline $\begin{array}{l}\text { Non-persistent } \\
\text { threats }\end{array}$ & $\begin{array}{l}\text { Investment attractiveness of the } \\
\text { agradian sector of the economy. } \\
\text { Production potential of the } \\
\text { agricultural industry. } \\
\text { Production costs of agricultural } \\
\text { products. } \\
\text { Production of staple food } \\
\text { products. }\end{array}$ & $\begin{array}{l}\text { Foreign trade in } \\
\text { food products }\end{array}$ & $\begin{array}{l}\text { Availability of basic means } \\
\text { of agricultural production. } \\
\text { Livestock population at } \\
\text { agricultural enterprises. } \\
\text { Sown areas of agricultural } \\
\text { crops. }\end{array}$ & $\begin{array}{l}\text { Influence of fertilization } \\
\text { condition of soil and product } \\
\text { quality. } \\
\text { Level of labour remuneration } \\
\text { in the country. } \\
\text { Environmental consequences } \\
\text { of land use. } \\
\text { Structure of land use. }\end{array}$ \\
\hline
\end{tabular}

Source: developed by the author 
supporting the level of food security at the appropriate level and on eliminating the threats. This is feasible by improving the competitiveness of domestic goods, increasing export potential, through the diversification of production. In terms of strategic perspective, it will contribute to strengthening the country's food security.

The non-persistent opportunities for food security in Ukraine manifest themselves in the foreign trade in food products that has demonstrated a modest growth in export over recent years, in the improved investment attractiveness of agrarian sector of the economy, in the growth in capital investments, with the level of unemployment in the country decreased in recent time. Strategic directions regarding the use of opportunities for strengthening food security, in this case, may include new investments to the agricultural sector of the economy, improvement in the competitiveness of domestic products and access to foreign markets, increase in food security indicators that characterize the affordability of food and the quality of nutrition.

The persistent threats to food security in Ukraine, according to data of the conducted analysis, include permanent unattractiveness of agrarian sector for workers, an insufficient number of people engaged in agriculture because of the low level of remuneration, lack of prestige to work in the agricultural sector. This, in turn, affects labour productivity and food security. The established persistent threats are the key obstacles that do not make it possible to effectively utilize the potential of the agricultural sector and threaten food security in general. Thus, it is necessary to maximally concentrate state resources on minimizing the negative impact of persistent threats on food security and, in a strategic perspective, to develop measures for eliminating them and for converting them into opportunities.

The non-persistent threats to food security include most of the identified characteristics:

- insufficient investment attractiveness of agrarian sector of the economy for foreign investors;

- ineffective implementation of the industrial potential of agricultural sector due to the fluctuations in yield and productivity of animals;

- the growth of production costs of agricultural products,

- fluctuations in the volume of food production, as well as import and export;

- insufficient availability of the basic means of production at agricultural enterprises and low level of technical equipment;

- the lack of stable growth in the sown areas and livestock population at agricultural enterprises;

- negative effect of fertilization on the condition of soil and product quality;

- the consequences of environmental problems of land use and failure to comply with the correct structure of land use;

- the low level of wages in the country, which does not allow people to have high-quality food in sufficient quantity.

The identified non-persistent threats under conditions of effective management could be converted into nonpersistent opportunities in a strategic perspective. The outlined circle of problems should be dealt with gradually, with the further development of strategic measures to neutralize them and protect food security and factors that affect it.

Thus, improving the efficiency of developing a state food security strategy requires the use of modern methods and tools of strategic analysis. The proposed original procedure for performing a strategic analysis of food security based on the SWOT-analysis is aimed at improving the process of strategy development, and thus will make it possible to optimize the allocation of resources and the search for directions to implement state policy in the agrarian sector of national economy, to regulate the internal market, social policy, by setting the priority of strategic measures.

\section{Conclusions}

The present study proposes an improved methodology of strategic analysis of food security based on the SWOT-analysis. Strategic analysis of food security can be conditionally divided into two blocks: analysis of the external environment and analysis of the internal environment.

To perform the analysis, we developed a system of indicators, which corresponds to the basic strategic groups of food security: production, market, resources, and consumption, in order to objectively establish strategic directions, responsible performers, resource allocation, and effective control over further development and implementation of the strategy. The indicators, derived from data about the last period of the analysis, are compared to values that are favourable for a specific criterion, or to normative values. As a result, we have obtained a system of relative magnitudes for the objective assessment of trends in food security.

A block of strategic analysis of the internal environment of food security implies the identification of strengths and weaknesses and the establishment of their persistence as it is necessary for determining strategic priorities and further effective allocation of resources when working out a strategy. It is proposed that persistent strengths and persistent opportunities of food security include those that maintain a positive tendency in the corresponding indicators over the examined period. Persistent weaknesses and persistent threats would include those that, on the contrary, demonstrate negative tendency in the corresponding indicators over the examined period.

Maximum attention in the course of development of the state strategy on food security will be required by persistent weaknesses, increased attention is to be 
paid to non-persistent weaknesses, and non-persistent strengths will need supporting measures whose intensity would depend on specific strategic priorities of the state policy in agricultural, trade and social fields. Persistent strengths should be utilized for the implementation of different measures in the strategy of food security.

A block of strategic analysis of the external environment of food security includes the assessment of threats and opportunities and the establishment of their persistence. Maximum attention should be paid to persistent threats and to development of measures to neutralize their impact; enhanced attention is to be paid to non-persistent threats. Persistent and non-persistent threats must be converted into opportunities of food security and into sources of its further strengthening. Non-persistent opportunities should be supported by appropriate strategic measures in the state's regulation of agricultural, foreign trade, social policy. Persistent opportunities will need strategic measures aimed at their maximum implementation in the long term.

Further scientific research should address the development of scientific methods and techniques for determining the mission and goals, for choosing a strategy and basic scenarios, for developing the strategy of food security using strategic planning tools, specifically, developing strategic maps.

\section{References:}

Ansoff, I. (1999). Novaya korporativnaya strategiya [New corporate strategy]. St. Petersburg: "Peter" (in Russian). Lebedev, K. N. (2008). Sistemnyy pokhod i metodologiya menedzhmenta [Systemic approach and methodology of management]. Moscow: "Red Book" (in Russian).

Aaker, D. (2002). Strategicheskoe rynochnoe upravlenie [Strategic market management]. St. Petersburg: "Peter" (in Russian).

Jalilo, Ya. A. (2011). Rozvytok ahrarnoho vyrobnytstva iak peredumova zabezpechennia prodovolchoi bezpeky Ukrainy: analitychna dopovid [Development of agrarian production as a prerequisite for ensuring food security in Ukraine: an analytical report]. NISS, Kyiv (in Ukrainian).

Thompson, A. A. \& Strickland, A. J. (1998). Strategicheskiy menedzhment. Iskusstvo razrabotki i realizatsii strategii [Strategic management. The art of developing and implementing a strategy]. Moscow: UNITY (in Russian).

Bowman, K. (1997). Osnovy strategicheskogo menedzhmenta [Fundamentals of Strategic Management]. Moscow: UNITY (in Russian).

Vikhansky, O. S. (2001). Strategicheskoe upravlenie [Strategic management]. Moscow: Gardarika (in Russian). Shershneva, Z. E. \& Oborskaya, S. V. (1999). Stratehichne upravlinnia [Strategic Management]. KNEU, Kyiv (in Ukrainian).

Gusev, Yu. V. (1992). Strategiya razvitiya predpriyatiy [Strategy of enterprise development]. St. Petersburg: "SPb UEF” (in Russian).

Mostova, A. D. \& Vinichenko I. I. (2016). Stratehiia iak instrument zabezpechennia ekonomichnoho rozvytku derzhavy [Strategy as an instrument for ensuring the economic development of the state]. Visnyk Dnipropetrovskoho derzhavnoho ahrarnoho universytetu [Bulletin of the Dnepropetrovsk State Agrarian University]. 3: pp. 91-96.

State Statistics Service of Ukraine (2018). Retrieved from: http://www.ukrstat.gov.ua (Accessed 25 January 2018) Skidan, O. V. (2004). Formuvannia rehionalnoi ahrarnoi polityky prodovolchoi bezpeky [The form of the regional agrarian policy of food and security] (PhD Thesis). Zhitomir.

Varaskina, O. V. (2016). Formuvannia orhanizatsijno-ekonomichnoho mekhanizmu prodovolchoi bezpeky $v$ Ukraini [The form of organisation-economical mechanism of food and beverages in Ukraine] (PhD Thesis). Poltava.

Halatur, S. M. (2015). Mekhanizm adaptatsii ahropromyslovoho kompleksu Ukrainy v umovakh hlobalnoi prodovolchoi problem [Mechanism of adaptation of agroindustrial complex of Ukraine in the conditions of global food problem]. Visnyk Dnipropetrovskoho derzhavnoho ahrarnoho universytetu [Bulletin of the Dnepropetrovsk State Agrarian University]. 3: pp. 114-116. 